\title{
Creativity in a COVID-19 Virtual Learning Space
}

\author{
Kathy O'Flynn-Magee \\ University of British Columbia, kathy.oflynnmagee@ubc.ca \\ Elizabeth J. Straus \\ University of British Columbia, elizabeth.straus@alumni.ubc.ca \\ Aneet Dhaliwal \\ University of British Columbia, aneet.dhaliwal@alumni.ubc.ca \\ Samantha-Ruth Chande \\ University of British Columbia, Samantha.chande@alumni.ubc.ca \\ Batool Alreffi \\ University of British Columbia, batool.Alreffi@ubc.ca \\ Prabhjot Randhawa \\ University of British Columbia, p.randhawa@alumni.ubc.ca \\ Yenlinh Chung \\ University of British Columbia, yenlinh.chung@alumni.ubc.ca \\ Salwa Khader \\ University of British Columbia, salwa.khader@alumni.ubc.ca
}

Follow this and additional works at: https://qane-afı.casn.ca/journal

\section{Recommended Citation}

O'Flynn-Magee, Kathy; Straus, Elizabeth J.; Dhaliwal, Aneet; Chande, Samantha-Ruth; Alreffi, Batool; Randhawa, Prabhjot; Chung, Yenlinh; and Khader, Salwa (2021) "Creativity in a COVID-19 Virtual Learning Space," Quality Advancement in Nursing Education - Avancées en formation infirmière: Vol. 7: Iss. 1, Article 2.

DOI: https://doi.org/10.17483/2368-6669.1284

This Article is brought to you for free and open access by Quality Advancement in Nursing Education - Avancées en formation infirmière. It has been accepted for inclusion in Quality Advancement in Nursing Education - Avancées en formation infirmière by an authorized editor of Quality Advancement in Nursing Education - Avancées en formation infirmière. 


\section{Creativity in a COVID-19 Virtual Learning Space}

\section{Cover Page Footnote}

Thank you to all the amazing teacher mentors and students with whom we have worked over the years. They have inspired us with some wonderfully creative teaching. The 'blowing bubbles' strategy is one example that has been passed down from educator to educator. At the time of writing, we do not know who originally designed this creative strategy. Merci à toutes les professeures-mentors et étudiantes extraordinaires avec qui nous avons travaillé au cours des années et qui ont su nous inspirer par leur enseignement créatif. La stratégie de «faire des bulles » est un exemple d'une approche transmise de formatrice à formatrice. Au moment de rédiger cet article, nous ne savons pas qui a mis de l'avant en premier cette stratégie créative. 


\section{Creativity in a COVID-19 Virtual Learning Space}

"Facilitating an online course in today's student population requires an educator to be innovative and creative and to have an impactful online presence" (Sharoff, 2019, Abstract).

\section{Background}

COVID-19 has turned the world upside down in many ways; its impact on education has been significant across the globe. Particularly disruptive has been the shift from in-person to virtual teaching and learning. Instead of co-creating and maintaining learning spaces that foster in-person dialogue, educators and students have had to quickly master the art of teaching and learning in a very different format. An added complexity was the perceived expectation that virtual classes would, for the most part, continue synchronously rather than transitioning to the typical asynchronous format of pre-COVID-19 online learning. This context emphasized the importance of designing and enacting teaching and learning experiences that fostered students' engagement through active learning (Sharoff, 2019). Yet with the sudden shift to online teaching during the early stages of the pandemic, the time to prepare was limited, and many educators scrambled to create online versions of previously designed in-person courses (Almost, 2020; Carolan, 2020; Williams, 2020). This was challenging in light of Sharoff's (2019) claim that one of the most important aspects of online teaching is a thoughtfully developed and clearly articulated design.

The authors of this paper experienced these time constraints in May 2020 when they engaged in a master's-level graduate course about clinical nursing education (CNE). This course is an elective within the Masters of Science in nursing (MSN) program and a required course within the Masters of Health Leadership and Policy (MHLP) program. In the former, students can choose to register for the course after they completed a prerequisite course; in the latter, the course is located in the second term of a three-term program. The course provides graduate students with a theoretical foundation to develop, or to enhance, their knowledge and skills as clinical education leaders or as clinical educators of nursing staff or students. Within this broad theoretical foundation, students explore teaching and learning strategies that can be used to foster an effective learning community, professional values, active learning, learner confidence, the development of teaching skills, and the consideration of issues that could arise in the clinical educator or leader role. Throughout the course, a number of teaching/learning strategies were used, requiring students to be actively engaged in the learning experiences. One of the unique aspects of this course is that it offers students the dual opportunity of both learning about strategies and experiencing those strategies as a learner. Our author team consists of one faculty course lead, one teaching assistant (TA) who is a PhD candidate, three MSN students, and three MHLP students from a university nursing program in Western Canada. Six of the 21 graduate students registered in the CNE course responded to our invitation to co-author this manuscript.

Despite the time constraints and COVID-19 challenges, our goals were to enact a teaching and learning experience that was as close as possible to the already designed in-person course in terms of creative teaching and learning strategies, student engagement, and active learning. In this paper, we describe the ways in which we chose to meet these goals, the lessons learned, and the implications for nursing education in the future.

\section{Conceptual Framework}

Our use of teaching and learning strategies was guided by the concept of active learning (Bonwell \& Eison, 1991; Sharoff, 2019). Bonwell and Eison (1991) describe active learning 
strategies as those that "involv[e] students in doing things and thinking about what they are doing" (p. iii). While active learning may involve physical doing, it is more about an active brain than a physically active student (Cambridge International Teaching \& Learning Team [CITLT], n.d.). Importantly, active learning allows students to maintain some control over their learning process, and instead of passively taking in information, students are invited to dig deeply and "think hard" (CITLT, n.d.). Active learning implies that students engage with the material, the environment, and the learning community. Engagement was especially important in the online synchronous environment because one of its known challenges is a lack of engagement (Kebritchi et al., 2017). Our choice of strategies was influenced by our goal to ensure that students could immerse themselves in a variety of learning experiences that were not only active and engaging but also creative.

Although creativity is not always well defined, it is acknowledged as an essential element of active learning (Rankin \& Brown, 2016). Renowned educationor Sir Ken Robinson (2006, 2017) explained creativity as "the process of developing original ideas that have value" (Rethinking Creativity section, para. 1). While creativity is often conceptualized at the individual level, Perry and Collier (2018) argue that "creativity is always part of particular locations, particular social and cultural moments in time and space, and part of particular histories and relations. [They] argue that creativity does not rest in individuals but is socially produced in relation; the extent to which we are creative is contingent on context" (p. 33). Conceptualizing creativity in this way enables consideration of how students, cultures, and contexts can influence the process of constructing and implementing our creative virtual teaching and learning strategies. Recognizing that creativity is often not prioritized in many higher education contexts, we consciously worked to co-create a culture in the course in which these strategies could be valued and successfully implemented.

There are numerous examples in the scholarly literature of creative teaching and learning approaches. Rieger et al. (2020) maintain that arts-based pedagogy (ABP) is itself a creative form. ABP includes, but is not limited to, the use of drama, poetry (McGarry \& Aubeeluck, 2013), drawing, painting, music (Lutter et al., 2018), and dancing (Steinhardt et al., 2020). Beyond ABP, creative teaching and learning strategies include the use of modified social activities such as speed dating (Muurlink \& Poyatos Matas, 2011), forum theatre (Boal, 1985; Diamond, 2007), teaching psychomotor skills (Atkinson, 2012) by learning how to blow a bubble, and gaming such as crossword puzzles (Gupta et al., 2015). Most of these ABPs and creative examples were designed primarily for the in-person learning context, and our challenge was to modify these strategies to ensure their fit into a synchronous virtual classroom. This challenge was, at times, daunting and sometimes felt risky for the educators. The risk was typically associated with the various creative approaches used by the educators, as some of the strategies were not activities that students might expect to see or experience in a graduate course. Our choice of strategies was influenced by previous use of several activities in the physical classroom. We discuss some of the strategies used in our online context that we believed were uncommon and of interest to the nursing education community; however, we acknowledge there are many other strategies that foster active learning. Although the primary author had used several of these strategies with good results in the physical classroom, there was risk associated with the virtual space and potential technical glitches that could occur when coordinating active learning strategies for the first time online. Regardless, we moved ahead, and this paper allows us to share our experiences with our use of gaming, use of bubble gum to teach psychomotor skills, speed dating, forum theatre, video-based learning, and found poetry in the virtual classroom. We also describe our use of an image-based activity in the physical classroom 
and offer suggestions for how it could be used online. Table 1 outlines the linkages between and among course learning outcomes, content, and processes.

\section{Table 1}

\section{Linkages to Course Outcomes}

\section{Select Course Learning Outcomes (LOs)}

1. Understand the theories and models of learning and teaching as they apply to clinical nursing education (CNE).

2. Appreciate the complexity of the learner-educator relationship and the context of the $\mathrm{CNE}$.

3. Use a variety of teaching strategies to enhance learning in the clinical setting.

4. Explore selected issues embedded in CNE.

5. Critique evidence-based literature that has relevance for CNE.

\begin{tabular}{|l|l|l|}
\hline Strategies & LOs & Course Content \\
\hline Crossword & 1,3 & Review of previous CNE course content \\
\hline Blowing bubbles & $1,2,3$ & Learning and teaching psychomotor skills \\
\hline Speed dating & $2,3,5$ & Diverse strategies for teaching and learning \\
\hline Forum theatre & $2,3,4$ & Bullying: An issue in CNE \\
\hline Video-based learning & $2,3,4$ & Learner-educator relationship \\
\hline Found poetry & $2,3,4$ & Narratives of students' experiences in CNE \\
\hline $\begin{array}{l}\text { Image-based } \\
\text { strategies }\end{array}$ & 2,3 & $\begin{array}{l}\text { Previous CNE course: The meaning of clinical } \\
\text { education and the role of the educator }\end{array}$ \\
\hline
\end{tabular}

\section{Strategies}

\section{Gaming}

Gamification is described as the use of game processes to enhance learning and enjoyment of problem-solving in non-gaming contexts (Orwoll et al., 2018; Sera \& Wheeler, 2017). We used gaming, in the form of a crossword puzzle, during the first class as a way to review previous coursework. Crossword puzzles were first introduced by Arthur Wynne in the "Fun" section of the New York World newspaper in 1913 and have since become one of the most popular word games 
in the world (Poston, 1998; Saxena et al., 2009). In our class, students were divided into teams in breakout rooms to complete a crossword puzzle designed by the course leader (https://www.education.com) in which the answers comprised theories and concepts addressed in a related (prerequisite for MHLP students) course completed the previous term. After, students returned to the larger group where ideas were shared and answers reflected upon. (See the Additional Files section on the article's home page for our readers' challenge: a crossword puzzle based on content in this paper).

Gupta et al.'s (2015) and Shawahna and Jaber's (2020) studies revealed that the use of crosswords enhanced learning for the majority of nursing and medical students. From our perspective, the interactive nature of the crossword puzzle did the same, fostering students' capacity to find proximity in the "virtual distance" and collaborate creatively to determine solutions. In hindsight, some of the challenges we encountered with the crossword activity could have been prevented by ensuring that each question had only one plausible answer, allocating enough time for everyone to finish, and making the crossword visually accessible throughout the activity. Despite these challenges, one student author stated, "The crossword puzzle activity was considered, by my classmates and me, a positive learning experience so much so that a few of us considered using it in [our] current practice or with [our] students in the future."

\section{Teaching the Psychomotor Skill of Blowing Bubbles}

Teaching psychomotor skills is an important role for clinical educators, and we used the skill of blowing bubbles with bubble gum to help students practice the art of teaching psychomotor skills. For this activity, the only instructions were "teach your partner how to blow a bubble using bubble gum"; students were asked in advance to have chewing gum on hand. Student pairs were then placed into breakout rooms and after 15 minutes were asked to return to the main room for a large-group debrief using the questions below:

1. What was that experience like for you?

2. As an educator?

3. As a learner?

4. What approach did you take?

5. What framework(s)/principles did you use?

Key learning from the debrief focused on the importance of assessing existing knowledge and skills, and pre-briefing on essential points such as "resist the urge to swallow the gum once you start chewing." Including all key steps to enable performance of the skill, such as bracing the gum against the teeth before pursing the lips and blowing was also essential. While the activity was designed for students to build knowledge of teaching psychomotor skills through an inductive learning approach, some of the student authors thought that outlining a step-by-step teaching process, such as the process advanced by Nicholls et al. (2016), could have supported a more consistent experience going into the activity. Psychomotor skills are indeed best taught in a structured, step by step approach, although the exact number of steps required can be debated (Nicholls et al., 2016). The class did, however, compare their teaching against a pre-made list of steps after the activity (Atkinson, 2012; National Association of EMS Educators, 2002), which enabled reflection on teaching technique and highlighted the need for the use of a framework.

Learning to teach psychomotor skills in this way really emphasized the importance of beginning with a learning needs assessment; for example, some learners knew not to swallow the gum, others did not. The learning activity was also useful in highlighting the need for a framework 
so that educators do not gloss over points that may seem obvious to them but not to the learner. Because chewing gum is a skill that is hidden in the mouth, it was a good way to practise descriptive communication rather than a different skill that could be more easily demonstrated over a video stream.

\section{Speed Dating}

Speed dating, as a social construct, offers individuals the opportunity to engage in several brief one-to-one interactions to get to know others as prospective romantic dates or future partners. In academic circles, speed dating has been reframed as speed networking (Muurlink \& Poyatos Matas, 2011) although we chose to use the term speed dating because of its social connection. In our online classroom environment, we modified the process to foster several one-to-one rotating discussions about teaching and learning strategies (see Figure 1). Students had been assigned a variety of readings and not all students reviewed the same material, so this activity fostered sharing ideas from the literature that may have been new for the student's "date." Students each had four "dates," and following the activity, we debriefed together as a large group.

\section{Figure 1}

\section{The Speed Dating Process}

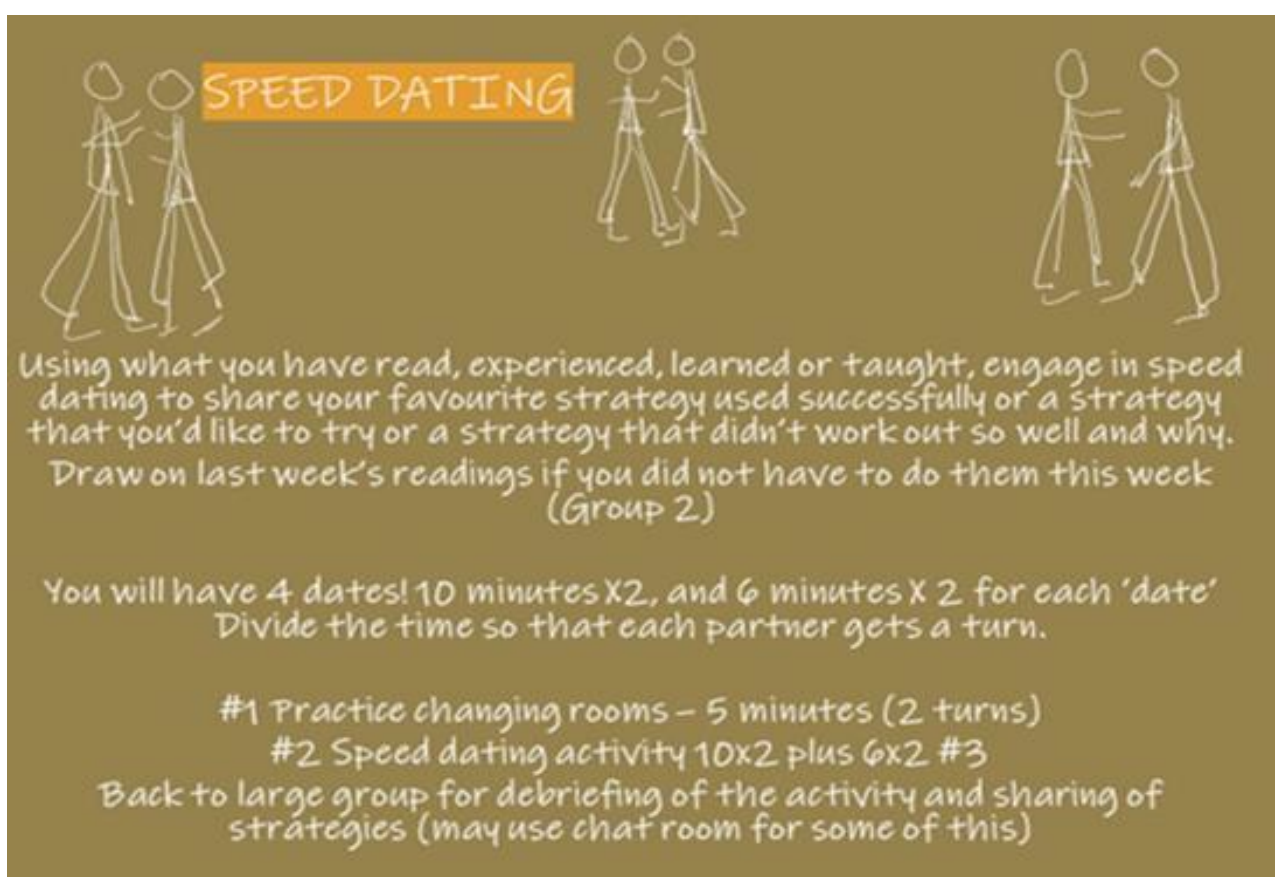

While some readers may be doubtful about the use of speed dating as an educational strategy, students in Jones and Ritter's (2020) study, although skeptical at first, described speed dating as a fun and positive experience that helped them remember challenging ideas. While it was certainly challenging to coordinate the process online, and we found no literature regarding its virtual use, both educators and students found it an engaging way to connect with peers and course content - so much so that students would have appreciated more time for each "date." According to one student author, "Speed dating not only provided valuable learning, it combated the loneliness and lack of interaction that accompanied the new online class format." 


\section{Arts-Based Pedagogy}

Arts-based pedagogy (ABP) is a creative and active learning-based strategy that draws on the arts as a way to foster meaningful learning for students (Rieger \& Chernomas, 2013; Rieger et al., 2020). In this paper, we describe ABP strategies through our use of forum theatre, video-based learning, found poetry, and image-based strategies.

\section{Forum Theatre}

Forum theatre originated in Brazil with Augusto Boal's (1985) "Theatre of the Oppressed" and has been taken up extensively by David Diamond (2007, personal communication, 2017, personal communication, 2018) to address issues of social justice in Canada. Forum theatre invites actors from the community in which the issue resides to perform a scripted play. The performance runs the first time without interruption, and the facilitator (the "joker" in forum theatre language) then invites the audience to intervene (i.e., replace one of the actors on stage) if they believe they have something to offer by taking on the role of one of the characters.

In our class, we used forum theatre to address the topic of bullying in nursing education. First, we had some information sharing about bullying in nursing education, and then faculty colleagues who were not involved in the course assumed the role of actors for a scripted performance that focused on a bullying situation between a registered nurse (RN) and a student. The session was facilitated by a colleague from our university's department of theatre and film. Having an expert "joker" was supportive and allowed students to acquire a glimpse of the role of an experienced joker. This process was especially important for students who were experiencing the activity at the same time as learning about the various strategies they might use in their own clinical education practice.

Forum theatre is a complex activity and engaging in it online was a leap into the unknown for our group. Some studies have explored its use in face-to-face nursing education spaces (Middlewick et al., 2012) and in conflict within general academia (Ryland \& Scholte, 2018). One challenge that is not uncommon to encounter within forum theatre is the unwillingness of audience members to get up on stage and intervene in the interaction(s) they have just witnessed. As one student author reflected,

At first, I believe a few of us felt a little unsure of how to engage in the activity, as it was so new and a little out of our comfort zone. However, after watching a few rounds of the performance, we began to realize that there was no 'right' answer and that the activity was really meant to provide us with a safe space for creativity and engagement in dealing with potential conflicts we may one day encounter.

\section{Video-Based Learning}

Hadi (2019) suggests that "in the present era of technology, students expect to have content that simulates reality and is available on demand" (p. 29). As a class, we experienced video-based learning through excerpts from two movies, Whiplash (Chazelle, 2014) and Dead Poet's Society (Weir, 1989). These short excerpts were chosen for their potential to evoke a powerful emotional response, for the differences between them, and for their relevance to the focus of the class which was learner/educator relationships. The video excerpts were emotionally charged and difficult to watch, yet they illustrated some nuanced behaviours that generated critical discussion. This opportunity for discussion, or debrief, was important to ensure that the video content was tied in to course concepts and allowed for the sharing of diverse perspectives. As articulated by one 
student author, who "...found video-based learning a great way to gain insight on a topic, such as relationships, that could not be portrayed in a typical lecture or role-play exercise."

Much like other forms of ABP, visual arts amplify affective and cognitive learning (Nguyen et al., 2016). Through integrating video-based learning methods, students may become more connected to the content they can see and hear (Hadi, 2019). These methods can also help students truly appreciate others' experiences (Lutter et al., 2018), as well as supporting reflective practice, critical analysis, and engagement in learning (Wright \& Charnock, 2018). At the same time, educators need to be thoughtful about movie scenes that may be potential triggers for students and, in advance, offer clear permission to stop watching if they feel uncomfortable. In our class experience, nobody voiced that they felt triggered or needed to step away from watching the video. Using this strategy online could be advantageous, as students can easily mute or look away if they feel they need to, without bringing attention to themselves for doing so. As educators, it is important to co-create a safe space and have resources available to provide adequate support for students.

\section{Found Poetry}

Poetry has been used as a pedagogical tool to enable learners to engage with the art of nursing and their own aesthetic way of knowing (Hunter, 2002; Uligraff, 2019). In our clinical education course, we used a form of poetry called found poetry when discussing the educatorstudent relationship and the experience of nursing students in clinical practice. Found poetry is created when key words and phrases are taken from a narrative source, merged together in a creative way, and presented in the form of a poem (Butler-Kisber, 2002). Each group was given a brief narrative from the literature of a pre-licensure student's experience of their clinical practice and educator involvement. Students were divided into groups and determined which words were most impactful to them and how they wanted to showcase them. At first, we, as students, felt unsure and anxious, but as we began to choose words that stood out, the poem began to take on a life of its own. It was particularly impactful to note how groups who were assigned the same narrative constructed very different found poems, each unique, meaningful, and significant. As voiced by one student author, "Found poetry took the learning from conceptual to emotional, allowing the information to be stored in a different, deeper part of my brain."

Found poetry has been used within multiple disciplines; however, there has been limited research within nursing education. Using found poetry to creatively summarize and analyze information, students have the opportunity to engage with aesthetic ways of knowing to enhance their emotional intelligence and knowledge retention (Hilbun, 2015; Hunter, 2002; Uligraff, 2019). Found poetry has also been shown to enable learners to uncover unexpected meanings and metaphors in a narrative (Cross \& Holyoake, 2017; Shaw \& Haney, 2017). Using poetry as a reflective tool, learners can creatively explore their own values and beliefs openly alongside those of their profession (Uligraff, 2019). As one student author said,

To be honest, it was quite beautiful to use our aesthetic way of knowing to discuss the reallife fears and experience our learners face within the nursing program. Personally, it is an experience and a teaching tool I will never forget and hope to continue using in my own practice, as a nurse and an educator. 


\section{Image-Based Strategies}

Another technique used in a previous in-person class with several of the same students was the use of images, art, and guided imagery to evoke reflection. Although our experience was in person, we believe this strategy could be easily adapted to the online environment. In the physical classroom, students were invited to select a picture from among those randomly spread across a table. These pictures included various images, photographs, and drawings from multiple print sources, including greeting cards and postcards (see Figure 2).

\section{Figure 2}

\section{Selection of Pictures and Postcards}

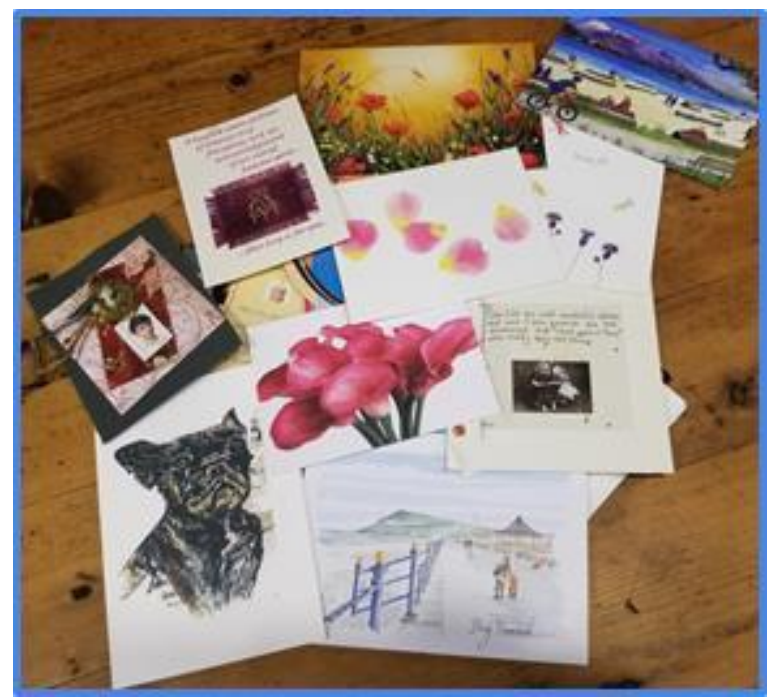

Students were asked to first self-reflect and then share the meaning of clinical education, the educator's role, and how this was represented in their chosen image. Some students used the picture as a metaphor, such as a basket symbolizing a toolbox of strategies they would gather. Others created stories and guided the class through a day as an educator or expressed the educatorstudent relationship. This strategy's effectiveness derives from the educator's ability to use art and pictures as a form of guided imagery to facilitate connections through metaphors, symbolism, and stories (Blomqvist et al., 2007; Nguyen et al., 2016; Segal-Engelchin et al., 2020). Such approaches can evoke students' emotional responses, prompting expressive dialogue, self-development, and thoughtful reflective practice (Brand \& McMurray, 2009; Lutter et al., 2018). By communicating their reflections, students essentially co-produced knowledge, which can help educators understand the group's subjective and social experiences, further guiding their teaching strategies (Segal-Engelchin et al., 2020).

To adapt this image-based activity to a virtual format, educators could display various images on the screen or ask students to locate an object within their immediate environment that represents a particular topic. Prompting questions could help guide students' reflection. If students are hesitant to communicate their reflection verbally, engagement could be facilitated through online whiteboards, - on which words and pictures can be drawn anonymously. This strategy could also be combined with breakout rooms or a think-pair-share activity that would allow for peer engagement. 


\section{Discussion}

Throughout the course, we drew on several active learning and creative learning-based strategies. Our choice of strategies was linked to the previously designed in-person course in which some of the same activities had been used successfully to engage students in active and creative ways. To summarize, strategies used included the use of a crossword to review previous course content, bubble gum to master the skill of teaching in the psychomotor domain, and speed dating to engage with several peers to discuss a variety of learning activities. Strategies also included $\mathrm{ABP}$, such as our use of forum theatre to address bullying, watching excerpts from two courserelevant movies to evoke emotion and to help bring the material alive, found poetry to capture the essence of undergraduate students' narratives of their experiences in clinical practice, and, finally, the use of image-based strategies in a previous course to explore the meaning(s) embedded in the chosen pictures. One student author said,

I recognize that these strategies are not for all topics or all learners. Still, when used for the context of aesthetic knowing and critical reflection, ABP can be a powerful tool for combining the physical and phenomenological experiences to gain deeper wisdom and understanding of the world.

Two key areas that we focus on in this discussion are (1) the risks embedded in co-creating a creative virtual classroom and (2) the creative role of technology in online teaching and learning.

\section{Risk-Taking}

It is interesting to reflect on risk-taking in terms of bringing in-class active learning and creative strategies online, as well as using social constructs such as speed dating in the virtual classroom. There is no doubt that "creativity is risky. It takes courage . . . it requires doing things differently ... [and] we make ourselves vulnerable to making mistakes ... [or] appearing foolish ... [and] creative endeavors don't always work out" (Beghetto, 2018, p. 18). Faculty leaders who are true leaders must regularly take risks, and those whose decisions are grounded in "doing the right thing" often find themselves obligated to take risks (Horton-Deutsch et al., 2014). Pardue et al. (2018) explored the role of risk-taking for faculty leaders in nursing and found that successful risk-taking required a willingness to fail, a commitment to learning from failure when it occurred, and a positive culture that supported experimentation, as well as the realities of risk- taking and failure.

Rankin and Brown's (2016) study highlighted the importance of a safe learning environment when using creative strategies, and especially relevant was the facilitator's role in creating such an environment. We agree that the learning environment and the relationships embedded within it are foundational for the development of inclusive spaces-perhaps especially so when educators are willing to take risks and invite students to join them in that journey. Coyle and Grant (2018) maintain that the opposite is true: taking risks first by being vulnerable is what leads to the trust that is so essential for thriving relationships between students and educators. Collier and colleagues (2018) remind us that it is within constructive relationships that meaningful learning can occur. We believe that such relationships make risk-taking more doable for both educators and students. Our goal in the course was to take "beautiful," rather than "good" or "bad," risks; a beautiful risk "involves taking actions that have the potential to make a positive and lasting contribution to the learning and lives of others" (Beghetto, 2018, p. 23). We argue that taking risks, being vulnerable, and sometimes failing should be welcomed additions to an authentic learning space. As knowledgeable educators, we have experienced some of our greatest learning(s), as well as many joyful moments, because we have gambled, allowed ourselves to be vulnerable, and 
sometimes failed. Given that clinical education was the focus of the course, it was our aim to model creativity in a COVID-19 virtual space context to enhance students' personal learning experiences. As well, we strove to be transparent about the risks taken, the failures that occurred, and the successes achieved so that students could benefit from our insights as educators when teaching learners with whom they worked. As voiced by one student author, "Using these learning methods in class has helped shape me as an educator as I implement them into my own teaching."

\section{Using Technology Creatively}

When teaching online, "faculty need to expand their educational processes to integrate technology as a tool and not as a pedagogical methodology" (Sharoff, 2019, para. 4). The required shift to online teaching during the pandemic, much of which has been synchronous, has presented unique opportunities to explore creative and innovative uses of technology. For the purposes of this discussion, we define technology as primarily the digital technologies, such as virtual meeting platforms, learning management systems (LMS), and internet-based tools, that support virtual learning. For those with less experience in online teaching and learning, it is easy to view technology as limiting the teaching strategies that can be employed in the virtual classroom. While strategies for supporting student engagement in online asynchronous courses are well-established, less attention has been paid to online synchronous classrooms. Considering Sharoff's (2019) suggestion of viewing technology as a tool shifts our focus from the limitations of technology toward the possibilities that technology presents as a tool for creative approaches to learning and developing a virtual community of inquiry. One student author said, "At first I thought a virtual platform would limit the creativity our class was known for. Turns out it actually offered us innovative ways for thinking out of the box and being more creative with our approaches to learning."

Reflecting on our experiences, we have identified several important lessons learned related to using technology as a tool through which creative active learning strategies are implemented in virtual contexts. Similar to studies of blended learning and synchronous online learning using technologies that were conducted pre-pandemic (Jowsey et al., 2020; O'Doherty et al., 2018), we noted that our ability to creatively use technology to support active learning was predicated on educator and student familiarity with the technology. For example, most of the strategies discussed in this paper required the use of breakout rooms, so it was important to ensure educators and students understood the capabilities of breakout rooms in the meeting platform being used. One approach we found particularly useful in supporting both faculty and students with strategies that involved more extensive use of technology was practice runs. For example, the logistics of the speed dating strategy required both educator and student knowledge of navigating between breakout rooms, allowing students to easily move from one room to another when it was time to move on to a new "date." Before class, the TA author prepared a handout with screenshots to help students visualize the steps they would need to go through to move between breakout rooms. While we initially encountered glitches in this process, students were able to move between rooms easily after some practice runs and use of the resources provided.

In addition, we realized early in the semester that students were not able to see our activity instructions once they moved into breakout rooms, so ensuring these were available through other platforms (e.g., LMS or Google Docs) allowed the activities to proceed smoothly. For the found poetry activity, for example, we posted the narratives from which students would generate found poems in the LMS so they could access the instructions on their own devices. Similarly, it was 
important to ensure there were options for students to record and share products of the activity, as work in breakout rooms typically cannot be recorded.

It is also important to examine differences in how students engage virtually. The literature on online teaching and learning pre-pandemic is rife with discussions of the importance of social connections and active engagement to dispel feelings of isolation students may experience in learning remotely through technology (Ferszt et al., 2019; Lowenthal \& Snelson, 2017). Engaging synchronously through virtual meeting platforms has been a particular challenge. Indeed, the student authors highlighted how it was more difficult to stay engaged for a three-hour class when sitting in front of the computer. The faculty and TA authors similarly recognized that student motivation, engagement, and energy varied when learning synchronously through technology. We have found that creative uses of technology served as an effective tool to support student engagement. We were thoughtful in ensuring that we varied not only the creative strategies used but also the positioning of these strategies during the three-hour class. For example, the speed dating activity was positioned in the second half of a class in which students had either just engaged in a debate or were observing a debate (an assessment strategy we used in the course, but that is beyond the scope of this paper). In this case, we wanted to allow students to engage in smaller breakout rooms after a long period of observing or debating. Additionally, each student had completed different readings about teaching strategies during this week, which enabled unique discussions to occur in the "dates" to broaden their exposure to different strategies. As suggested by Oermann (2015), we remained attentive to selecting creative strategies that aligned with and enabled the achievement of class outcomes.

\section{Summary and Conclusion}

(A found poem created by the authors to capture the essence of this paper)

COVID-19 Turned World Upside Down

Complex, Challenging, Disruptive,

Clinical Education Educators and Wannabes

Synchronous, Evidence-Based

What to Do, What to Do?

Scramble

Active, Engaging, Creative, Learning \& Teaching

Art_Theatre_Video_Found Poetry

Psychomotor_Speed Dating_Gaming.

Deep, Control, Vulnerable, Positive

Active our goal, Technology our tool

Active, Engaging, Creative, Learning \& Teaching

Educators Take Risks, Students Join Journey

Not just any risk but a "beautiful" risk

Rich. Flexible. Adaptable

Learned valuable lessons. 
Eager for Life. Grateful for Learning.

Active, Engaging, Creative, Learning \& Teaching

In conclusion, as voiced by one student author, "We are all eager for life to go back to normal, but in all honesty, I feel grateful to have gone through this difficult yet rich virtual learning experience. As future educators, we have certainly learned valuable lessons on flexibility and adaptation." 


\section{References}

Almost, J. (2020). The impact of COVID-19 within academic settings: A high-speed pivot. Canadian Journal of Nursing Leadership, 33(3), 15-19.

Atkinson, S. P. (2012). Using Dave's psychomotor domain taxonomy across all tertiary level programmes. https://sijen.com/tag/daves-taxonomy/

Beghetto, R. (2018). Taking beautiful risks in education. Educational Leadership: The Arts and Creativity in Schools, 76(4), 18-24.

Blomqvist, L., Pitkälä, K., \& Routasalo, P. (2007). Images of loneliness: Using art as an educational method in professional training. The Journal of Continuing Education in Nursing, 38(2), 89-93. https://doi.org/10.3928/00220124-20070301-05

Boal, A. (1985). Theatre of the oppressed. Theatre Communications Group, Inc.

Bonwell, C. C., \& Eison, J. A. (1991). Active learning: Creating excitement in the classroom (ASHE-ERIC Higher Education Rep. No. 1). The George Washington University, School of Education and Human Development.

Brand, G., \& McMurray, A. (2009). Reflection on photographs: Exploring first-year nursing students' perceptions of older adults. Journal of Gerontological Nursing, 35(11), 30-37. https://doi.org/10.3928/00989134-20091001-03

Butler-Kisber, L. (2002). Artful portrayals in qualitative inquiry: The road to found poetry and beyond. Alberta Journal of Educational Research, 48(3), 29.

Cambridge International Teaching \& Learning Team. (n.d.). Getting started with active learning. https://www.cambridge-community.org.uk/professional-development/gswal/index.html

Carolan, C. (2020). COVID 19: Disruptive impacts and transformative opportunities in undergraduate nurse education. Nurse Education in Practice, 46, 102807. https://doi.org/10.1016/j.nepr.2020.102807

Chazelle, D. (Director). (2014). Whiplash [Film]. Bold films, Blumhouse Production, \& Right of Way Films.

Collier, M., Sánchez, R. M., \& Wix, L. (2018). Aesthetic education: Surviving challenging times. The Journal of Aesthetic Education, 52(3), 107-120. https://doi.org/10.5406/jaesteduc.52.3.0107

Coyle, D., \& Grant, A. (2018, April 2). The process of building trust works in the opposite way that you think it does. https://qz.com/work/1241911/daniel-coyle-author-of-thetheculture-code-says-building-trust-works-in-theopposite-way-you-think-it-does

Cross, V., \& Holyoake, D. (2017). "Don't just travel”: Thinking poetically on the way to professional knowledge. Journal of Research in Nursing, 22(6-7), 535-545. https://doi.org/10.1177/1744987117727329

Diamond, D. (2007). Theatre for living: The art and science of community-based dialogue. Trafford Publishing.

Ferszt, G. G., Dugas, J., McGrane, C., \& Calderelli, K. (2019). Creative strategies for teaching millennial nursing students. Nurse Educator, 42(6), 275-276. https://doi.org/10.1097/NNE.0000000000000384 
Gupta, U., Gupta, N. K., Sinhal, P., Gupta, S., \& Mahdi, F. (2015). Creative learning using crossword puzzle as learning tool for undergraduates in obstetrics and gynecology. Journal of Contemporary Medical Education, 3(1), 36-39. https://doi.org/10.5455/jcme.20150508051013

Hadi, Y. (2019). The effect of video-based learning on medical imaging students' clinical performance. Radiologic Science \& Education, 24(2), 29-41.

Hilbun, J. (2015). Find poetry: Using found poems in school and public libraries to enhance student creativity and writing. Journal of Research on Libraries and Young Adults, 6. http://www.yalsa.ala.org/jrlya/2015/11/find-poetry-using-found-poems-in-school-andpublic-libraries-to-enhance-student-creativity-and-writing/

Horton-Deutsch, S., Pardue, K., Young, P. K., Morales, M. L., Halstead, J., \& Pearsall, C. (2014). Becoming a nurse faculty leader: Taking risks by doing the right thing. Nursing Outlook, 62(2), 89-96 https://doi.org/doi:10.1016/j.outlook.2013.12.003

Hunter, L. P. (2002). Poetry as an aesthetic expression for nursing: A review. Journal of Advanced Nursing, 40(2), 141-148. https://doi.org/10.1046/j.1365-2648.2002.02356.x

Jones, M. M., \& Ritter, L. J. (2020). "The dating game": Using speed dating in the college classroom. College Teaching, 68(3), 105-111. https://doi.org/10.1080/87567555.2020.1752615

Jowsey, T., Foster, G., Cooper-Ioelu, P., \& Jacobs, S. (2020). Blended learning via distance in pre-registration nursing education: A scoping review. Nurse Education in Practice, 44, 102775. https://doi.org/10.1016/j.nepr.2020.102775

Kebritchi, M., Lipschuetz, A., \& Santiague, L. (2017). Issues and challenges for teaching successful online courses in higher education: A literature review. Journal of Educational Technology Systems, 46(1), 4-29. https://doi.org/10.1177/0047239516661713

Lowenthal, P. R., \& Snelson, C. (2017). In search of a better understanding of social presence: An investigation into how researchers define social presence. Distance Education, 38(2), 141-159. https://doi.org/10.1080/01587919.2017.1324727

Lutter, S., Pucino, C., \& Jarecke, J. (2018). Arts-based learning strategies in clinical post conference: A qualitative study. Journal of Nursing Education, 57(9), 549-553. https://doi.org/10.3928/01484834-20180815-07

McGarry, J., \& Aubeeluck, A. (2013). A different drum: An arts-based educational program. Nursing Science Quarterly, 26(3), 267-273.https://doi.org/10.1177/0894318413489200

Middlewick, Y., Kettle, J., \& Wilson, J. (2012). Curtains up! Using forum theatre to rehearse the art of communication in healthcare education. Nurse Education in Practice, 12(3), 139142. https://doi.org/10.1016/j.nepr.2011.10.010

Muurlink, O., \& Poyatos Matas, C. (2011). From romance to rocket science: Speed dating in higher education. Higher Education Research \& Development, 30(6), 751-764. https://doi.org/10.1080/07294360.2010.539597 
National Association of EMS Educators. (2002). National Guidelines for EMS Instructors: Module 17: Teaching Psychomotor Skills.

https://one.nhtsa.gov/people/injury/ems/instructor/instructor_ems/2002_national_guidelin es.htm

Nguyen, M., Miranda, J., Lapum, J., \& Donald, F. (2016). Arts-based learning: A new approach to nursing education using andragogy. Journal of Nursing Education, 55(7), 407-410. https://doi.org/10.3928/01484834-20160615-10

Nicholls, D., Sweet, L., Muller, A., \& Hyett, J. (2016). Teaching psychomotor skills in the twenty-first century: Revisiting and reviewing instructional approaches through the lens of contemporary literature. Medical Teacher, 38(10), 1056-1063. https://doi.org/10.3109/0142159X.2016.1150984

O’Doherty, D., Dromey, M., Lougheed, J., Hannigan, A., Last, J., \& McGrath, D. (2018). Barriers and solutions to online learning in medical education-An integrative review. BMC Medical Education, 18(1), 130. https://doi.org/10.1186/s12909-018-1240-0

Oermann, M. (2015). Technology and teaching innovations in nursing education: Engaging the student. Nurse Educator, 40(2), 55-56. https://doi.org/10.1097/NNE.0000000000000139

Orwoll, B., Diane, S., Henry, D., Tsang, L., Chu, K., Meer, C., Hartman, K., \& Roy-Burman, A. (2018). Gamification and microlearning for engagement with quality improvement (GAMEQI): A bundled digital intervention for the prevention of central line-associated bloodstream infection. American Journal of Medical Quality, 33(1), 21-29. https://doi.org/10.1177/1062860617706542

Pardue, K. T., Young, P. K., Horton-Deutsch, S., Halstead, J., \& Pearsall, C. (2018). Becoming a nurse faculty leader: Taking risks by being willing to fail. Nursing Forum, 53(2), 204212. https://doi.org/10.1111/nuf.12244

Perry, M., \& Collier, D. R. (2018). What counts as creativity in education? An inquiry into the intersections of public, political, and policy discourses. Canadian Journal of Education, 4l(1), 24-43.

Poston, I. (1998). Crossword puzzles: Adjunct clinical teaching strategy. Journal of Nursing Education, 37(6), 266-267.

Rankin, J., \& Brown, V. (2016). Creative teaching method as a learning strategy for student midwives. Nurse Education Today, 38, 93-100. https://doi.org/10.1016/j.nedt.2015.12.009

Rieger, K. L., \& Chernomas, W. M. (2013). Arts-based learning: Analysis of the concept for nursing education. International Journal of Nursing Education Scholarship, 10(1), 1-10. https://doi.org/10.1515/ijnes-2012-0034

Rieger, K. L., Chernomas, W. M., McMillan, D. E., \& Morin, F. L. (2020). Navigating creativity within arts-based pedagogy: Implications of a constructivist grounded theory study. Nurse Education Today, 91, 104465. https://doi.org/10.1016/j.nedt.2020.104465

Robinson, K. (2006). Do schools kill creativity? TED Talk at a TED conference available at: https://www.ted.com/talks/sir_ken_robinson_do_schools_kill_creativity

Robinson, K. (2017). Out of our minds: The power of being creative (3rd ed.). Wiley and Sons. 
Ryland, M., \& Scholte, T. (2018). Rehearsing resilience (and beyond): Facilitating second order observation of conflict in the university workplace through forum theatre. Kybernetes, 48(4). 740-750. https://doi.org/10.1108/K-11-2017-0459

Saxena, A., Nesbitt, R., Pahwa, P., \& Mills, S. (2009). Crossword puzzles: Active learning in undergraduate pathology and medical education. Archives of pathology \& laboratory medicine, 133(9), 1457-1462.

Segal-Engelchin, D., Huss, E., \& Massry, N. (2020). Arts-based methodology for knowledge coproduction in social work. The British Journal of Social Work, 50(4), 1277-1294. https://doi.org/10.1093/bjsw/bcz098

Sera, L., \& Wheeler, E. (2017). Game on: The gamification of the pharmacy classroom. Currents in Pharmacy Teaching and Learning, 9(1), 155-159. https://doi.org/10.1016/j.cptl.2016.08.046

Sharoff, L. (2019). Creative and innovative online teaching strategies: Facilitation for active participation. Journal of Nursing Education, 16(2). https://doi.org/10.9743/JEO.2019.16.2.9

Shaw, J., \& Haney, K. A. (2017). A thought exercise: Thinking through the found poetry of Canadian abortion providers. Journal of Poetry Therapy, 30(3), 175-188. https://doi.org/10.1080/08893675.2017.1328861

Shawahna, R., \& Jaber, M. (2020). Crossword puzzles improve learning of Palestinian nursing students about pharmacology of epilepsy: Results of a randomized controlled study. Epilepsy \& Behavior, 106, 107024.

Steinhardt, S. J., Kelly, W. N., Clark, J. E., \& Hill, A. M. (2020). An artistic active-learning approach to teaching a substance use disorder elective course. American Journal of Pharmaceutical Education, 84(4), 498-503. https://doi.org/10.5688/ajpe7634

Uligraff, D. K. (2019). Utilizing poetry to enhance student nurses' reflective skills: A literature review. Belitung Nursing Journal, 5(1), 3-8. https://doi.org/10.33546/bnj.631

Weir, P. (1989). Dead poet's society [Film]. Touchstone Pictures, \& Silver Screen Partners IV.

Williams, J. A. (2020). Did the scramble to remote learning work? Chronicle of Higher Education, 66(36), 5.

Wright, N., \& Charnock, D. (2018). Challenging oppressive practice in mental health: The development and evaluation of a video-based resource for student nurses. Nurse Education in Practice, 33, 42-46. https://doi.org/10.1016/j.nepr.2018.08.016 